\title{
Examining the common aetiology of serous ovarian cancers and basal-like breast cancers using double primaries
}

\author{
Colin B Begg ${ }^{\star}, 1$, Megan S Rice ${ }^{2}$, Emily C Zabor ${ }^{1}$ and Shelley S Tworoger ${ }^{3}$ \\ ${ }^{1}$ Department of Epidemiology and Biostatistics, Memorial Sloan Kettering Cancer Center, New York, NY 10017, USA; \\ ${ }^{2}$ Massachusetts General Hospital and Harvard Medical School, Boston, MA 02115, USA and 'Brigham and Women's Hospital, \\ Harvard Medical School and Harvard T.H. Chan School of Public Health, Boston, MA 02115, USA
}

Background: The somatic molecular profiles of basal-like breast cancers and high-grade serous ovarian cancers share many similarities, leading to the hypothesis that they have similar aetiologies, in which case they should occur together in the same patient more often than expected.

Methods: We identified 545 women with double independent primary cancers of the breast and ovary reported to the California Cancer Registry from 1999 to 2013 and examined the coincidence of subtype combinations.

Results: For most subtype combinations the observed frequencies were similar to their expected frequencies, but in 103 observed cases vs 43.8 expected $(\mathrm{O} / \mathrm{E}=2.35 ; 95 \% \mathrm{Cl} 1.90-2.81)$ a triple-negative breast tumour (typically basal-like) was matched with a serous ovarian tumour (typically high-grade).

Conclusions: The results provide compelling evidence that basal-like breast cancer and high-grade serous ovarian cancer share a much more similar aetiology than breast and ovarian cancers more broadly. Further research is needed to clarify the influence of germ-line BRCA1 mutations and other risk factors on these results.

In recent years, investigators have paid increasing attention to the sub-classification of cancer. In a detailed analysis in The Cancer Genome Atlas (TCGA), the molecular portrait of basal-like breast cancers was observed to have similar characteristics to that of highgrade serous ovarian tumours (Cancer Genome Atlas Network, 2012). Both subtypes exhibited a very high frequency of TP53 mutations, evidence of mutations in NF1 and $R B 1$ at lower frequencies, BRCA1 and BRCA2 inactivation, and similar copy number gains and losses. Bioinformatic pattern recognition methods have also suggested that these tumour types are characterised by mutually exclusive loss of function in the same pathways (Cancer Genome Atlas Network, 2012; Ciriello et al, 2012). The authors of the TCGA report of breast cancer suggested that these results indicated a related aetiology' of these tumour subtypes (Cancer Genome Atlas Network, 2012). Our purpose was to test this hypothesis by assessing whether triple-negative breast cancers (as a surrogate for basal-like tumours) and serous ovarian cancers (most of which are high-grade) occur together more frequently in the same patient than expected. Our premise is that if risk profiles of two subtypes are correlated in the population, then these subtypes are more likely to co-occur in the same patient (Begg, 2011).

\section{MATERIALS AND METHODS}

Since 1999, the California Cancer Registry has routinely collected information on breast tumour markers, including oestrogen

*Correspondence: Dr CB Begg; E-mail: beggc@mskcc.org

Received 8 December 2016; revised 23 February 2017; accepted 1 March 2017; published online 23 March 2017

(C) 2017 Cancer Research UK. All rights reserved 0007-0920/17 
receptor (ER), progesterone receptor $(\mathrm{PR})$ and human epidermal growth factor receptor 2 (HER2). These markers can be used to approximately classify patients into four breast cancer subtypes: luminal $\mathrm{A}(\mathrm{ER}+$ or $\mathrm{PR}+$, and HER2 -$)$; luminal $\mathrm{B}(\mathrm{ER}+$ or $\mathrm{PR}+$, and HER +$)$; HER2 enhanced $(\mathrm{ER}-, \mathrm{PR}-$ and HER 2 - ); and triple negative (ER,- PR - and HER2 - ). The California Cancer Registry also collected information on histologic subtypes of epithelial ovarian cancer, including the four most common subtypes: serous; endometrioid; mucinous; and clear cell. We obtained the frequencies of the subtypes of all incident cases of either cancer during the period 1999-2013, as well as the frequencies and subtypes of all cases with multiple primaries. We then used these data to compare the observed vs expected cooccurrences of all subtype combinations among all women diagnosed with both a primary breast cancer and a primary ovarian cancer.

For each of the 16 possible combinations of subtypes of the two diseases, we enumerated the observed number of cases with the specific subtype combination. This observed total was then divided by an expected value to determine which subtype combinations occurred more frequently together than expected. The expected values were calculated by multiplying the total number of observed cases with both a breast and an ovarian primary by the relative frequencies of the specific subtypes observed among all cases of cancer. These relative frequencies are provided in Supplementary Table 1. The resulting $\mathrm{O} / \mathrm{E}$ ratio represents a ratio of two standardised incidence ratios. The denominator is a measure of how strongly the aetiologies of breast and ovarian cancer overall are related, while the numerator reflects the corresponding strength of the relationship between the two subtypes under consideration. Thus, if the $\mathrm{O} / \mathrm{E}$ ratio is elevated it suggests that the two subtypes share a more similar aetiology than breast and ovarian cancers overall, and vice versa. The rationale for these calculations is explained in detail in the Supplementary Methods.

\section{RESULTS}

We excluded ovarian adenocarcinomas or carcinomas with histology designated as 'other' and restricted the analysis to breast cancers for which tumour markers were available (74\% of all breast cancer cases). Our final analytic sample included 545 women with one breast and one ovarian primary cancer that had known subtypes, but excluded 72 paired breast-ovary tumours from cases with three or more primaries and five synchronous cases. The results were not materially affected by these exclusions (data not shown). The observed and expected values for all subtype combinations are provided in Table 1 . The results show a large 2.35 -fold increase over expectation in the co-occurrence of triplenegative breast cancers with serous ovarian cancers. None of the other combinations of subtypes demonstrated any convincing trends, although in three combinations the co-occurrence was marginally significantly lower than expected (luminal B breast and serous ovarian; luminal $\mathrm{A}$ and mucinous; and luminal $\mathrm{A}$ and endometrioid). However, as the total observed and expected frequencies are constrained to be equivalent, the other combinations must compensate with lower observed rates to offset the large excess co-occurrence of serous ovarian and triple-negative breast cancers.

When we stratified by order of diagnosis (breast cancer first $v s$ ovarian cancer first), we observed significantly elevated occurrence of the triple-negative breast/serous ovarian cancer double primary combination in both strata. When the breast cancer occurred first, there were 73 cases observed vs 25.9 expected $(\mathrm{O} / \mathrm{E}=2.8,95 \%$ confidence interval 2.2-3.5), and when the ovarian cancer was diagnosed first there were 30 observed $v s 17.9$ expected $(\mathrm{O} / \mathrm{E}=1.7$, 95\% confidence interval 1.1-2.3).

\section{DISCUSSION}

These results provide compelling support for the hypothesis that the risk profiles for basal-like breast cancer and high-grade serous ovarian cancer are strongly correlated. That is, individuals with a high risk for basal-like breast cancer will typically also experience a high risk for high-grade serous ovarian cancer, and vice versa. This knowledge should facilitate a purposeful search for the risk factors common to these subtypes. Relatively little is known about risk factors specifically for high-grade serous and basal-like breast cancers. Although reproductive and hormonal risk factors do not clearly overlap between serous and triple-negative breast cancer, what is highly consistent is that established hormonal risk factors for breast and ovarian cancers overall are much more weakly associated with these subtypes compared to other breast or ovarian subtypes (Anderson et al, 2014; Wentzensen et al, 2016).

Table 1. Observed vs expected counts for combinations of subtypes in double primary cases of breast and ovarian cancers

\begin{tabular}{|c|c|c|c|c|c|}
\hline & & \multicolumn{3}{|c|}{ Double primary cases } & $95 \%$ confidence $^{b}$ \\
\hline Luminal A & $\begin{array}{l}\text { Serous } \\
\text { Endometrioid } \\
\text { Clear cell } \\
\text { Mucinous }\end{array}$ & $\begin{array}{r}236 \\
50 \\
27 \\
26\end{array}$ & $\begin{array}{r}245.1 \\
64.3 \\
31.4 \\
37.1\end{array}$ & $\begin{array}{l}0.96 \\
0.78 \\
0.86 \\
0.70\end{array}$ & $\begin{array}{l}0.84-1.09 \\
0.56-0.99 \\
0.54-1.18 \\
0.43-0.97\end{array}$ \\
\hline Luminal B & $\begin{array}{l}\text { Serous } \\
\text { Endometrioid } \\
\text { Clear cell } \\
\text { Mucinous }\end{array}$ & $\begin{array}{r}32 \\
9 \\
7 \\
7\end{array}$ & $\begin{array}{r}43.1 \\
11.3 \\
5.5 \\
6.5\end{array}$ & $\begin{array}{l}0.74 \\
- \\
- \\
-\end{array}$ & $\begin{array}{c}0.49-1.00 \\
- \\
- \\
-\end{array}$ \\
\hline HER2 enhanced & $\begin{array}{l}\text { Serous } \\
\text { Endometrioid } \\
\text { Clear cell } \\
\text { Mucinous }\end{array}$ & $\begin{array}{r}25 \\
2 \\
2 \\
1\end{array}$ & $\begin{array}{r}21.2 \\
5.6 \\
2.7 \\
3.2\end{array}$ & $\begin{array}{l}1.18 \\
- \\
- \\
-\end{array}$ & $\begin{array}{c}0.72-1.64 \\
- \\
- \\
-\end{array}$ \\
\hline Triple negative & $\begin{array}{l}\text { Serous } \\
\text { Endometrioid } \\
\text { Clear cell } \\
\text { Mucinous }\end{array}$ & $\begin{array}{r}103 \\
13 \\
4 \\
1\end{array}$ & $\begin{array}{r}43.8 \\
11.5 \\
5.6 \\
6.6\end{array}$ & $\begin{array}{c}2.35 \\
1.13 \\
- \\
-\end{array}$ & $\begin{array}{c}1.90-2.81 \\
0.52-1.74 \\
- \\
-\end{array}$ \\
\hline
\end{tabular}


An obvious candidate that may explain a portion of the risk association is the presence of a BRCA1 germ-line mutation. Previous studies have shown that germ-line mutations in BRCA1 are more frequent in serous ovarian cases than other ovarian subtypes, and considerably more frequent in triple-negative breast cases than other breast cancer subtypes, suggesting that BRCA1 germ-line mutations represent an important risk factor that explains a portion of the elevated concordance between triplenegative breast and serous ovarian cancers in our study (Mavaddat et al, 2012). Further, although the prevalence of BRCA1 mutations in the USA population is low, the high relative risks of breast and ovarian cancer among mutation carriers lead to much higher prevalences of germ-line BRCA1 mutations in cases, and especially in those with double primaries. While among breast cancer patients in northern California the prevalence of BRCA1 mutations is only about $2 \%$ (John et al, 2007), the prevalence in ovarian cancer patients is higher $(\sim 13 \%$ for $B R C A 1$ and $B R C A 2$ combined) (Arts-de Jong et al, 2016) and the reported prevalence in cases with double breast-ovary primaries is higher still, in the region of 35\% (Evans et al, 2010; Cvelbar et al, 2011; Pilarski et al, 2012). Clearly, a study involving genotyping would be necessary to resolve the extent to which these mutations may explain the increased similarity of the risk profiles of basal-like breast and high-grade serous ovarian cancers. Conversely, there are also important distinctions between these subtypes in that by definition triple-negative tumours are ER negative, whereas serous ovarian tumours are predominantly ER positive, suggesting that while there must be important commonalities in their risk profiles there must also be important differences (Shafrir et al, 2016).

It is interesting that we did not observe evidence of a shared aetiology for the other subtype combinations, even though, for example, luminal breast cancers and endometrioid ovarian cancers are characterised by hormone receptor expression (Anderson et al, 2014) and have similar reproductive risk factors (Hecht et al, 2009).

One limitation of our study is that treatment for the first primary cancer could differentially impact incidence of subtypes of the second primary tumour. For example, bilateral oophorectomy for ovarian cancer treatment may lower the incidence of hormonally sensitive luminal A breast tumours more than triplenegative tumours (Press et al, 2011; Boggs et al, 2014). Subtype misclassification is also an issue, although ovarian cancer histology is reasonably well classified and subtyping for breast cancer was relatively standardised during the period of our study (Köbel et al, 2013). Further, we used triple-negative breast cancers as a surrogate for basal-like, recognising that only about $80 \%$ of triple negatives will be truly basal-like (Rakha and Ellis, 2009; Curtis et al, 2012). While we were unable to characterise serous ovarian cancer by grade, few serous tumours are low-grade (Matsuno et al, 2013). Despite these potential sources of bias, we believe that the results are sufficiently strong that they provide substantial evidence of the common aetiology of basal-like breast cancer and high-grade serous ovarian cancer. It is critical to identify both shared and nonshared risk factors for high-grade serous and basal-like breast cancer as these are the most aggressive types of these cancers. Further research should examine risk factor profiles of tumours across anatomic sites that share molecular features.

\section{ACKNOWLEDGEMENTS}

We are grateful to Brenda Giddings and the California Cancer Registry for supplying the data. This work was supported by grants R01 CA163251 (NCI NIH) to CBB, P30 CA008748 (NCI NIH) to CBB and ECZ, and P01 CA87969 (NCI NIH) to SST.

\section{CONFLICT OF INTEREST}

The authors declare no conflict of interest.

\section{REFERENCES}

Anderson KN, Schwab RB, Martinez ME (2014) Reproductive risk factors and breast cancer subtypes: a review of the literature. Breast Cancer Res Treat 144: $1-10$.

Arts-de Jong M, de Bock GH, van Asperen CJ, Mourits MJ, de Hulla JA, Kets CM (2016) Germline BRCA1/2 mutation testing is indicated in every patient with epithelial ovarian cancer: a systematic review. Eur J Cancer 61: 137-145.

Begg CB (2011) A strategy for distinguishing optimal cancer sub-types. Int J Cancer 129: 931-937.

Boggs DA, Palmer JR, Rosenberg L (2014) Bilateral oophorectomy and risk of cancer in African American women. Cancer Causes Control 25: 507-513.

Cancer Genome Atlas Network (2012) Comprehensive molecular portraits of breast tumors. Nature 490: 61-70.

Ciriello G, Cerami E, Sander C, Schultz N (2012) Mutual exclusivity analysis identifies oncogenic network modules. Genome Res 22: 398-406.

Curtis C, Shah SP, Chin SF, Turashvili G, Rueda OM, Dunning MJ, Speed D, Lynch AG, Samarajiwa S, Yuan Y, Gräf S, Ha G, Haffari G, Bashashati A, Russell R, McKinney S. METABRIC GroupLangerød A, Green A, Provenzano E, Wishart G, Pinder S, Watson P, Markowetz F, Murphy L, Ellis I, Purushotham A, Børresen-Dale AL, Brenton JD, Tavaré S, Caldas C, Aparicio S (2012) The genomic and transcriptomic architecture of 2000 breast tumours reveals novel subgroups. Nature 486: 346-352.

Cvelbar M, Hocevar M, Vidmar G, Teugels E (2011) BRCA1/2 status and clinicopathologic characteristics of patients with double primary breast and ovarian cancer. Neoplasma 58: 198-204.

Evans DG, Ahmed M, Bayliss S, Howard E, Lalloo F, Wallace A (2010) BRCA1, BRCA2, and CHEK2 c.100 delC mutations in patients with double primaries of breast and/or ovaries. J Med Genet 47: 561-566.

Hecht JL, Kotsopoulos J, Hankinson SE, Tworoger SS (2009) Relationship between epidemiologic risk factors and hormone receptor expression in ovarian cancer: results from the Nurses' Health Study. Cancer Epidemiol Biomarkers Prev 18: 1624-1630.

John EM, Miron A, Gong G, Phipps AI, Felberg A, Li FP, West DW, Whittemore AS (2007) Prevalence of pathogenic BRCA1 mutation carriers in 5 US racial/ethnic groups. JAMA 298: 2869-2876.

Köbel M, Kalloger SE, Lee S, Duggan MA, Kelemen LE, Prentice L, Kalli KR, Fridley BL, Visscher DW, Keeney GL, Vierkant RA, Cunningham JM, Chow C, Ness RB, Moysich K, Edwards R, Modugno F, Bunker C, Wozniak EL, Benjamin E, Gayther SA, Gentry-Maharaj A, Menon U, Gilks CB, Huntsman DG, Ramus SJ, Goode EL. Ovarian Tumor Tissue Analysis consortium (2013) Biomarker-based ovarian carcinoma typing: a histologic investigation in the ovarian tumor tissue analysis consortium. Cancer Epidemiol Biomarkers Prev 22: 1677-1686.

Matsuno RK, Sherman ME, Visvanathan K, Goodman MT, Hernandez BY, Lynch CF, Ioffe OB, Horio D, Platz C, Altekruse SF, Pfeiffer RM, Anderson WF (2013) Agreement for tumor grade of ovarian carcinoma: analysis of archival tissues from the surveillance, epidemiology, and end results residual tissue repository. Cancer Causes Control 24: 749-757.

Mavaddat N, Barrowdale D, Andrulis IL, Domchek SM, Eccles D, Nevanlinna H, Ramus SJ, Spurdle A, Robson M, Sherman M, Mulligan AM, Couch FJ, Engel C, McGuffog L, Healey S, Sinilnikova OM, Southey MC, Terry MB, Goldgar D, O’Malley F, John EM, Janavicius R, Tihomirova L, Hansen TV, Nielsen FC, Osorio A, Stavropoulou A, Benítez J, Manoukian S, Peissel B, Barile M, Volorio S, Pasini B, Dolcetti R, Putignano AL, Ottini L, Radice P, Hamann U, Rashid MU, Hogervorst FB, Kriege M, van der Luijt RB, HEBON, Peock S, Frost D, Evans DG, Brewer C, Walker L, Rogers MT, Side LE, Houghton C. EMBRACE Weaver J, Godwin AK, Schmutzler RK, Wappenschmidt B, Meindl A, Kast K, Arnold N, Niederacher D, Sutter C, Deissler H, Gadzicki D, Preisler-Adams S, Varon-Mateeva R, Schönbuchner I, Gevensleben H, Stoppa-Lyonnet D, Belotti M, Barjhoux L. GEMO Study Collaborators Isaacs C, Peshkin BN, Caldes T, de la Hoya M, Cañadas C, Heikkinen T, Heikkilä P, Aittomäki K, Blanco I, Lazaro C, Brunet J, Agnarsson BA, Arason A, Barkardottir RB, Dumont M, Simard J, Montagna M, Agata S, D'Andrea E, Yan M, Fox S. kConFab Investigators Rebbeck TR, Rubinstein W, Tung N, Garber JE, Wang X, Fredericksen Z, Pankratz VS, Lindor NM, Szabo C, Offit K, 
Sakr R, Gaudet MM, Singer CF, Tea MK, Rappaport C, Mai PL, Greene MH, Sokolenko A, Imyanitov E, Toland AE, Senter L, Sweet K, Thomassen M, Gerdes AM, Kruse T, Caligo M, Aretini P, Rantala J, von Wachenfeld A, Henriksson K. SWE-BRCA Collaborators Steele L, Neuhausen SL, Nussbaum R, Beattie M, Odunsi K, Sucheston L, Gayther SA, Nathanson K, Gross J, Walsh C, Karlan B, Chenevix-Trench G, Easton DF, Antoniou AC. Consortium of Investigators of Modifiers of BRCA1/2 (2012) Pathology of breast and ovarian cancers among BRCA1 and BRCA2 mutation carriers: results from the Consortium of Investigators of Modifiers of BRCA1/2 (CIMBA). Cancer Epidemiol Biomarkers Prev 21: 134-147.

Pilarski R, Patel DA, Weitzel J, McVeigh T, Dorairaj JJ, Heneghan HM, Miller N, Weidhaas JB, Kerin MJ, McKenna M, Wu X, Hildebrandt M, Zelterman D, Sand S, Shulman LP (2012) The KRAS variant is associated with risk of developing double primary breast and ovarian cancer. PLoS One 7: e37891.

Press DJ, Sullivan-Halley J, Ursin G, Deapen D, McDonald JA, Strom BL, Norman SA, Simon MS, Marchbanks PA, Folger SG, Liff JM, Burkman RT, Malone KE, Weiss LK, Spirtas R, Bernstein L (2011) Breast cancer risk and ovariectomy, hysterectomy, and tubal sterilization in the women's contraceptive and reproductive experiences study. Am J Epidemiol 173: 38-47.

Rakha EA, Ellis IO (2009) Triple-negative/basal-like breast cancer: review. Pathology 41: 40-47.
Shafrir AL, Rice MS, Gupta M, Terry KL, Rosner BA, Tamimi RM, Hecht JL, Tworoger SS (2016) The association between reproductive and hormonal factors and ovarian cancer by estrogen- $\alpha$ and progesterone receptor status. Gynecol Oncol 143: 628-635.

Wentzensen N, Poole EM, Trabert B, White E, Arslan AA, Patel AV, Setiawan VW, Visvanathan K, Weiderpass E, Adami HO, Black A, Bernstein L, Brinton LA, Buring J, Butler LM, Chamosa S, Clendenen TV, Dossus L, Fortner R, Gapstur SM, Gaudet MM, Gram IT, Hartge P, Hoffman-Bolton J, Idahl A, Jones M, Kaaks R, Kirsh V, Koh WP, Lacey Jr JV, Lee IM, Lundin E, Merritt MA, Onland-Moret NC, Peters U, Poynter JN, Rinaldi S, Robien K, Rohan T, Sandler DP, Schairer C, Schouten LJ, Sjöholm LK, Sieri S, Swerdlow A, Tjonneland A, Travis R, Trichopoulou A, van den Brandt PA, Wilkens L, Wolk A, Yang HP, Zeleniuch-Jacquotte A, Tworoger SS (2016) Ovarian cancer risk factors by histologic subtype: an analysis from the Ovarian Cancer Cohort Consortium. J Clin Oncol 34: 2888-2898.

This work is published under the standard license to publish agreement. After 12 months the work will become freely available and the license terms will switch to a Creative Commons AttributionNonCommercial-Share Alike 4.0 Unported License.

Supplementary Information accompanies this paper on British Journal of Cancer website (http://www.nature.com/bjc) 